\title{
Collaboration rules should reflect investment
}

Florence. Any new country wishing to join a major European collaborative research venture should be required to demonstrate that it is making sufficient domestic investment in science to be able to benefit directly from such collaboration, Antonio Ruberti, the former European commissioner for research, suggested last week.

At the same time, new rules need to be developed for scientific collaboration with major industrial nations - in particular the United States and Japan - to allow Europe to benefit from the strengths it has built up over the past several decades, and ensure that it is no longer treated as a 'junior partner' in any global co-operative venture.

Both suggestions emerged at the end of a three-day meeting held in Florence to discuss the lessons to be drawn from almost 50 years of experience in European scientific collaboration - starting with those efforts, such as the building of the European Laboratory for Particle Physics (CERN), which have their roots in the reconstruction of the continent at the end of the Second World War - and to suggest how such lessons might guide future plans.

Furthermore, both reflect a growing shift in the attitude of European politicians towards collaborative ventures. There is now a reduced emphasis on the potential political value of such ventures, and increased concern for their cost-effectiveness, judged primarily in scientific and technological terms.

The meeting provided some clear divergences of view on both the lessons of the past, and their implications for the future. Organized by the European University Institute, and funded by a grant from the European Commission, it provided an opportunity for several historians of science to provide evidence of the extent to which, during this period, collaboration has been driven as much by political as scientific considerations.

In some instances, the historians' analysis received wide support. There was general endorsement, for example, for a statement by John Krige, one of the organizers of the conference who is currently writing a history of the European Space Agency (ESA), that post-war scientific collaboration in Europe must take the desire to both compete and collaborate with the United States as "a fundamental point of reference".

But several other conclusions from the historians received a more critical response from the second main group represented at the Florence meeting, namely scientists and government officials responsible for specific collaborative efforts.

There were, for example, some sceptical responses from those reluctant to emphasize the links between science and politics to the suggestion of Krige and his colleague
Dominique Pestre, a historian of post-war French physics, that the construction of CERN had been implicitly endorsed by Europe's military establishment because of its potential, if indirect, contribution to new nuclear technologies.

Yet whatever the disagreements between the historians and practitioners of collaboration, consensus emerged on several key points. One was that there is "no optimal model" for scientific collaboration, the

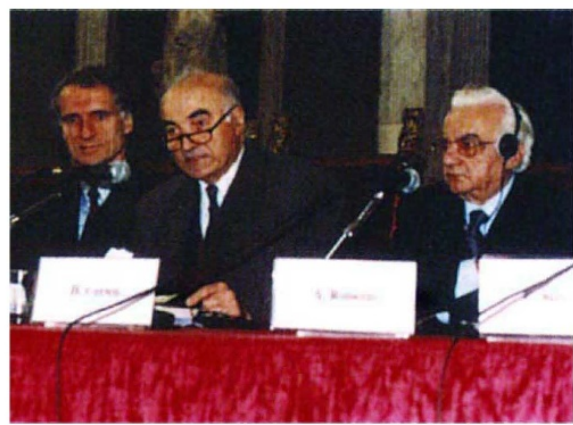

Hubert Curien (centre), the former French research minister, addresses last week's meeting, flanked by Bertel Haarder (left) of Denmark and Antonio Ruberti (right) of Italy.

nature of successful institutional arrangements depending highly on the specific goal being pursued.

A second point of virtually unanimous agreement was that a high price for European-wide collaboration is paid by scientists in terms of the time-consuming bureaucratic hurdles over which funding applications for joint research projects have to pass.

Some blamed this excessive bureaucracy on the enthusiasm of politicians for policies of juste retour - the idea that an individual country's contribution to a particular project should be reflected in the share of industrial contracts it receives - and the resulting need felt by administrators to be able to justify all decisions in this context.

Others, such as Jean Pierre Contzen, director general of the commission's Joint Research Centre in Ispra, Italy, highlighted the way restrictions imposed for political reasons can reduce the flexibility of European Union (EU) institutions to react flexibly to new challenges.

Indeed, there was widespread support for a call from Sir John Kendrew, former director general of the European Molecular Biology Laboratory (EMBL), for a serious study of the relationship between science and bureaucracy. "Many scientists think that there has become too much of it," he said.

A third point of apparent consensus was a feeling that the rules for membership of European-wide projects, many of which were originally established to deal with the relatively small number of countries making up western Europe, need to be reassessed in the light of growing demands for member- ship from the newly independent states of eastern European.

Tensions on this issue have been increasing steadily over the past few years, originating not in opposition to the principle that such states be permitted to join established collaborative projects, but in the distortions that their presence may cause to established procedures, ranging from voting rules based on the concept of 'one country, one vote', to the application of juste retour principles.

Such pressures are being felt intensely, for example, by CERN. After the collapse of communism, CERN agreed to admit a number of new eastern European countries on relatively generous terms. But CERN's director general, Christopher Llewellyn Smith, told the meeting that the pressures of expanded membership, coinciding with increased demands from member states for a distribution of service contracts that reflects their financial contribution to the agency, meant it was unlikely to be equally generous to those now knocking at the door.

Some suggested that membership rules adopted by bodies created more recently, and thus able to base their practice on the experiences of their predecessors, offered possible solutions. Yves Petroff, for example, director general of the European Synchrotron Radiation Facility in Geneva, pointed to the success of a rule that smaller countries could only become members as part of a consortium contributing a total of at least four per cent of the overall costs.

Ruberti's proposal was even more radical, namely that the government of any country seeking to participate in joint European projects be required to demonstrate a domestic commitment to increased funding for science before being allowed to do so. Ruberti's proposal reflects the principle of 'convergence' already adopted as the basis of future monetary union in the EU, namely that this be restricted to those able to meet a fixed set of economic criteria.

"We have to take on board the different levels of research efforts in different countries, and to become aware of the need for convergence in national efforts," said Ruberti. Without this, he added, it was difficult to endorse cooperation between countries "which sometimes differ by a factor of six in terms of the proportion of national product spent on research.'

Several other participants at the meeting supported the idea, pointing out that it could be used to encourage poorer countries within the EU to use the so-called 'structural funds', intended by Brussels to help build up their economic infrastructure, to strengthen their scientific and technological capabilities, rather than using such funds solely for more conventional infrastructure projects, such as road-building. How Brussels reacts remains to be seen.

David Dickson 